\title{
Human cryptosporidiosis: detection of specific antibodies in the serum by an indirect immunofluorescence*
}

\section{Anticorpos específicos para a criptosporidiose humana detectados mediante imunofluorescência indireta}

\author{
Lúcia M.A. Braz, Vicente Amato Neto, Clara I.L. Ferrari, Maria C.A. Palhares, Valdir S. \\ Amato, Márcia T.F. Santos, Heloísa H.S. Marques, Marcelo Vallada, Laura S.S. Nakanishi e \\ Heitor F. Andrade Júnior \\ Instituto de Medicina Tropical da Universidade de São Paulo. São Paulo, SP - Brasil \\ (L.M.A.B.,H.F.A.Jr.); Hospital das Clínicas da Faculdade de Medicina da Universidade de São Paulo. \\ São Paulo, SP-Brasil (V.A.N., V.S.A., H.H.S.M., M.V., L.S.S.N.); Laboratório Regional de Araçatuba do \\ Instituto Biológico de São Paulo. Secretaria da Agricultura. Araçatuba, SP - Brasil (C.I.L.F.); \\ Laboratório do Centro de Referência e Treinamento - AIDS da Secretaria de Saúde. São Paulo, SP . \\ Brasil (M.C.A.P., M.T.F.S.)
}

\begin{abstract}
Cryptosporidium sp., a coccidian parasite usually found in the faeces of cattle, has been recently implicated as an agent of human intestinal disease, mainly in immunocompromised patients. In the study realized, by an indirect immunofluorescence technique, specific immunoglobulins ( $\operatorname{IgG}$ and $\operatorname{IgM}$ ) have been demonstrated in human serum against Cryptosporidium oocysts. Purified oocysts were used as antigens in the indirect immunofluorecence assay. After analyzing this test in sera from selected groups of patients, the frequency of both specific IgG and IgM of immunocompetent children who were excreting oocysts in their faeces was $62 \%$ and in children with negative excretion of oocysts was $20 \%$ and $40 \%$, respectively. In adults infected with the human immunodeficiency virus (HIV) and who were excreting Cryptosporidium in their stools, the frequency was $57 \%$ for IgG but only $2 \%$ for IgM. Twenty three percent of immunocompromised adults with not determined excretion of oocysts in their stools had anti-Cryptosporidium IgG in their sera. Children infected with human immunodeficiency virus had no IgM and only $14 \%$ had IgG detectable in their sera. The indirect immunoflorescence assay, when used with other parasitological techniques appears to be useful for retrospective population studies and for diagnosis of acute infection. The humoral immune response of HIV positive patients to this protozoan agent needs clarification.
\end{abstract}

Fluorescent antibody technique, indirect. Cryptosporidium, immunology. Antibodies, protozoan.

\footnotetext{
* Presented at "XI Reunião da Sociedade Brasileira de Protozoologia - Caxambu, MG - 6 a 8.11.95; part the Thesis of Lúcia M.A. Braz, presented to the "Instituto de Ciências Biomédicas - Universidade de São Paulo. Supported by "Laboratório de Investigação Médica-46 and Laboratório de Investigação Médica-49 of HC-FMUSP".

Correspondence to: Lúcia M.A. Braz - Laboratório de Investigação Médica/Parasitologia do Instituto de Medicina Tropical da Universidade de São Paulo. Av. Dr. Enéas Carvalho de Aguiar, 500 - 1ํandar - 05403-900 São Paulo, SP - Brasil. Fax:(55.11) 852.3622 E-mail: lmabraz@usp.br The publication of this article was sponsored by FAPESP (Process 95/2290-6)

Received on 27.11.1995. Approved on 17.4.1996.
} 


\begin{abstract}
Resumo
Utilizando a técnica de imunofluorescência indireta, foram demonstradas imunoglobulinas $G$ e $M$, no soro humano, contra o Cryptosporidium, coccídeo implicado recentemente como agente de doença intestinal humana, principalmente em pacientes imunocomprometidos. Foi obtida positividade de $62 \%$ para imunoglobulinas $G$ e $M$ nos soros das crianças immunocompetentes com oocistos nas fezes e, respectivamente, 20\% e 40\%, nos soros das crianças sem oocistos. Nos pacientes adultos, com o vírus da imunodeficiência humana e excreção fecal do parasita, foram encontrados índices de positividade de 57\% da IgG mas apenas $2 \%$ para IgM e aqueles com excreção não determinada apresentaram 23\% da IgG. Crianças com o vírus da imunodeficiência humana, apresentaram apenas $14 \%$ da IgG e foram negativas quanto à IgM. Os resultados apontaram para a utilidade do teste, associado a outras técnicas parasitológicas, em estudos populacionais retrospectivos ou diagnósticos na infecção aguda e, ainda, que a resposta imune humoral a este protozoário necessita de maiores investigações, nos pacientes imunocomprometidos, principalmente crianças.
\end{abstract}

Técnica indireta de fluorescência para anticorpo. Cryptosporidium, imunologia. Anticorpos antiprotozoários.

\section{INTRODUCTION}

Cryptosporidium sp., a coccidian parasite, common in cattle, causes human intestinal disease both in immunocompetent and immunocompromised patients. It is usually associated with HIV infection, where it carries a bad prognosis. Cryptosporidium has been reported to be a contributing factor in the death of two malnourished children ${ }^{15}$.

Most attention has been focused on studies of the immunology of cryptosporidiosis and its role in pathogenesis because of the severity of the disease in immmunocompromised individuals ${ }^{29}$.

Although the host defense mechanisms responsible for controlling Cryptosporidium infections are poorly understood ${ }^{29}$, many studies demonstrated the development of specific serum $\operatorname{IgG}^{7}, \operatorname{Ig}^{13}, \operatorname{IgM}^{24}$ and $\operatorname{IgE}^{3}$ responses in humans and other animals ${ }^{16}$.

Approximately $10 \%$ of AIDS patients in the United States develop cryptosporidiosis; in the developing world the number is estimated to be between 30 and $50 \%{ }^{20}$. At "Hospital das Clínicas da Faculdade de Medicina da Universidade de São Paulo", Guizelini found Cryptosporidium in $21.25 \%$ (17/80) of AIDS patients with diarrhea and in $12.10 \%$ (58/479) of immunocompetent children with diarrhea ${ }^{8}$.
Usually, the diagnosis of this disease is based on the morphological identification of oocysts of the parasite in stool, processed and stained by methods such as acid-fast, Kinyoun ${ }^{14}$, Ziehl-Nielsen ${ }^{23}$ with subsequent microscopic examination. These tests have low sensitivity, which can be explained by variable affinity of dyes for the oocyst wall or by intermittent excretion of oocysts in stool ${ }^{6}$. Alternative methods for antigen detection have been proposed, such as ELISA and IIF test using monoclonal antibodies $^{23}$.

The detection of specific antibodies in sera can be useful in seroprevalence studies, given its simplicity and capacity to demonstrate past infection, specially in self-limiting disease that occurs in immunocompetent patients. These patients might play a role in spreading Cryptosporidium to the environment ${ }^{26}$.

In the present study, specific $\operatorname{IgG}$ and $\operatorname{IgM}$ antibodies to Cryptosporidium sp. in sera from selected groups of patients were detected and quantified, using an indirect immunofluorescence assay. Patients groups were stratified by age and immunological status, and the humoral response to this coccidia compared amongst the different groups. The relevance of this test in epidemiological studies is discussed. 


\section{MATERIAL AND METHOD}

\section{Antigen}

Oocysts from stools of infected calves were concentrated by centrifugation at $1,500 \mathrm{~g}, 20$ minutes, at $4^{\circ} \mathrm{C}$. The sediment was carefully washed three times in an equal volume of PBS $(0.01 \mathrm{M}$ phosphate-buffered saline, pH 7.2) supplemented with $1 \%$ Tween 80 . The final pellet was resuspended and applied over a discontinuous sucrose gradient.

This gradient was prepared from Sheather solution ( $320 \mathrm{ml} \mathrm{H} \mathrm{H}_{2} \mathrm{O}, 500 \mathrm{~g}$ sucrose and $9 \mathrm{ml}$ phenol). The concentrate solution of sucrose was diluted in PBS with $1 \%$ Tween 80 in order to obtain two specific gradients of 1,064 and $1,103 \mathrm{~g} / \mathrm{ml}$. In a polypropylene conical centrifuge tube, $15 \mathrm{ml}$ of the 1,064 solution was layered over $15 \mathrm{ml}$ of the 1,103 solution and $5 \mathrm{ml}$ of oocyst suspension placed on top. These gradients were centrifuged at $1,500 \mathrm{~g}$ for 30 minutes at $4^{\circ} \mathrm{C}$. The interface pellet from the layers was washed in PBS with one part per hundred of an antibioticantimycotic mixture containing penicillin $(10,000 \mathrm{U} / \mathrm{ml})$ and amphotericin B (Fungizone) $(25 \mu \mathrm{g} / \mathrm{ml})^{9}$ and concentrated by centrifugation as above described.

The pellet recovered from the last sucrose gradients was cetrifuged in a specific gradient of 1,103 and 1,064 of Ficoll-Hypaque (720 ml Ficoll, $300 \mathrm{ml}$ Hypaque at 34\%Urografina 370 -Berlimed). In 2 Ultra-clear centrifuge tubes (Beckman) of $12 \mathrm{ml}, 5 \mathrm{ml}$ of specific gradient of 1,064 was put on top of $5 \mathrm{ml}$ of specific gradient of 1,103 and on top of the two gradients, samples of $2 \mathrm{ml}$ each of oocysts. This gradient was centrifuged at $100,000 \mathrm{~g}$ for 30 minutes at $4^{\circ} \mathrm{C}$ in an ultracentrifuge (Beckman). The oocysts rich layers, betwen 1,103 and 1,064, were washed in PBS 3 times, at 1,000 g, for 20 minutes and the oocysts were quantified in $1 \mathrm{~mm}^{3}$ in a Neubauer hemacytometer.

\section{Serum Samples}

Sera were selected from immunocompromised (HIV) and immunocompetent patients with negative, not determined and positive identification of Cryptosporidium oocysts in their faeces, determined by the acid fast technique of Kinyoun, and stored at $-20^{\circ} \mathrm{C}$ for up to 3 years.

The groups of patients studied were:

Group A - 13 sera of immunocompetent (non HIV) children (age ranging from 4 months to 8 years) with known fecal excretion of Cryptosporidium oocysts;

Group B - 5 sera of immunocompetent (non HIV) children (age ranging from 7 months to 3 years) with negative fecal excretion of Cryptosporidium oocysts;

Group C - 7 sera of immunodeficient (HIV positive) children (age ranging from 7 months to 5 years) with known fecal excretion of Cryptosporidium oocysts;
Group D - 1 serum of immunocompetent (non HIV) adult with known fecal excretion of Cryptosporidium oocysts;

Group E - 70 sera from blood donors with excretion of Cryptosporidium oocysts not determined;

Group F - 51 sera of immunodeficient (HIV positive) adults (age ranging from 24 to 54 years) with known fecal excretion of Cryptosporidium oocysts;

Group G - 22 sera of immunodeficient (HIV positive) adults (age ranging from 20 to 45 years) with excretion of Cryptosporidium oocysts not determined;

Group H - 4 sera of laboratory workers (age ranging from 23 to 55 years) with excretion of Cryptosporidium oocysts not determined;

Group I - 9 sera of patients with toxoplasmosis;

4 sera of patients with Isospora belli and HIV;

4 sera of patients with Giardia lamblia;

1 serum of patient with malaria;

2 sera of patients with calazar;

4 sera of patients with Chagas disease and HIV;

5 sera of patients with schistosomiasis.

\section{Serological methods - \\ Indirect Immunofluorescence (IIF)}

After quantification, the slides were prepared with $5 \mu 1\left(3.3 \times 10^{4}\right)$, of a PBS solution containing $6.6 \times 10^{6}$ oocysts $/ \mathrm{ml}$, dropped in each well of the slide and stored at $20^{\circ} \mathrm{C}$, for up to one year.

The oocysts-coated slides were defrosted, fixed in cold acetone (MERCK) for 10 minutes and washed in PBS for 10 minutes, at room temperature. After this, the slides were dried, incubated at $37^{\circ} \mathrm{C}$ for 10 minutes and submitted to the test.

Serial twofold dilutions of each coded serum beginning at 1:10 were prepared in PBS and $25 \mu \mathrm{l}$ of diluted sera were placed in the antigen slides and incubated at $37^{\circ} \mathrm{C}$ for 40 minutes in a humid chamber. After two washings of 10 minutes each in PBS - 1\% BSA (Albumin bovine Sigma), the slides were blot dried and incubated with 25 $\mu \mathrm{l}$ of fluorescein iso/thiocyanate/anti-human, IgM and IgG conjugate, diluted 1:500 and 1:100, respectively, in Evan's blue counterstain. Optimum dilutions of conjugate were determined by checker board titrations. The slides were then placed in a moist chamber for 40 minutes, at $37^{\circ} \mathrm{C}$. As before, the slides were washed twice in PBS, for 10 minutes each, and dried. Buffered glycerin, $\mathrm{pH} 9.0$, diluted in PBS and a cover-glass were added. The reactions were examined in a Zeiss, epifluorescence microscope with appropriate filters, at $400 \mathrm{X}$ and 1,000 X magnifications.

A positive and a negative control serum, and phosphate buffered saline were included in each run. Indirect immunofluorescence reactions, whose titers were determined in a blind protocol, were repeated a minimum of 4 times for each serum sample and read by two observers. Fluorescence was read only on morphologically characteristic oocysts. 
Upon testing for $\operatorname{IgM}$, each serum was previously absorbed with RF-Absorbens(Behring) (anti-rheumatoid factor). After being diluted in $1.5 \mathrm{ml}$ of sterile distilled water, as described in the kit protocol, the absorbent RFA was mixed vol./vol. in 1:5 diluted serum. The mixture was incubated for 15 minutes at room temperature, shaken for 1 minute and centrifuged at $650 \mathrm{~g}$. The supernatant was used for the IIF test at a dilution of 1:10.

\section{Absorption of anti-Toxoplasma Gondii Antibodies}

To demonstrate the specificity of anti-Cryptosporidium IgG, a $T$. gondii antigen preparation was used. The suspected serum (a patient with IgG against Cryptosporidium and against Toxoplasma gondii) and a serum from a patient with IgG against $T$. gondii only, were absorbed with formalized and lyophilized taquizoites of $T$. gondii, RH strain. Briefly, a 1:10 dilution of $T$. gondii was mixed with twofold serum dilutions and incubated overnight with shaking at $4^{\circ} \mathrm{C}$. The suspension was centrifuged at $1,000 \mathrm{~g}$ for 20 minutes. The supernatant and pellet were used, respectively, as serum in IIF and as antigens in IIF reactions in order to detect antibodies present in sera or bound to $T$. gondii taquizoites in pellets.

\section{Statistical Analysis}

The chi-square test corrected by Yates and MantelHaenszel was applied for the analysis of the numerical differences in antibody production in the several groups. The difference in titers was submitted to the Kruskal-Wallis analysis. In all calculations, the level of significance considered significant was less than $0.05(\mathrm{p}<0.05)^{28}$.

\section{RESULTS}

In our test, positive sera had a characteristic IIF pattern, with a bright, yellow-greenish fluorescence seen on the oocysts wall (Fig. 1A) and not seen in negative sera (Fig. 1B).
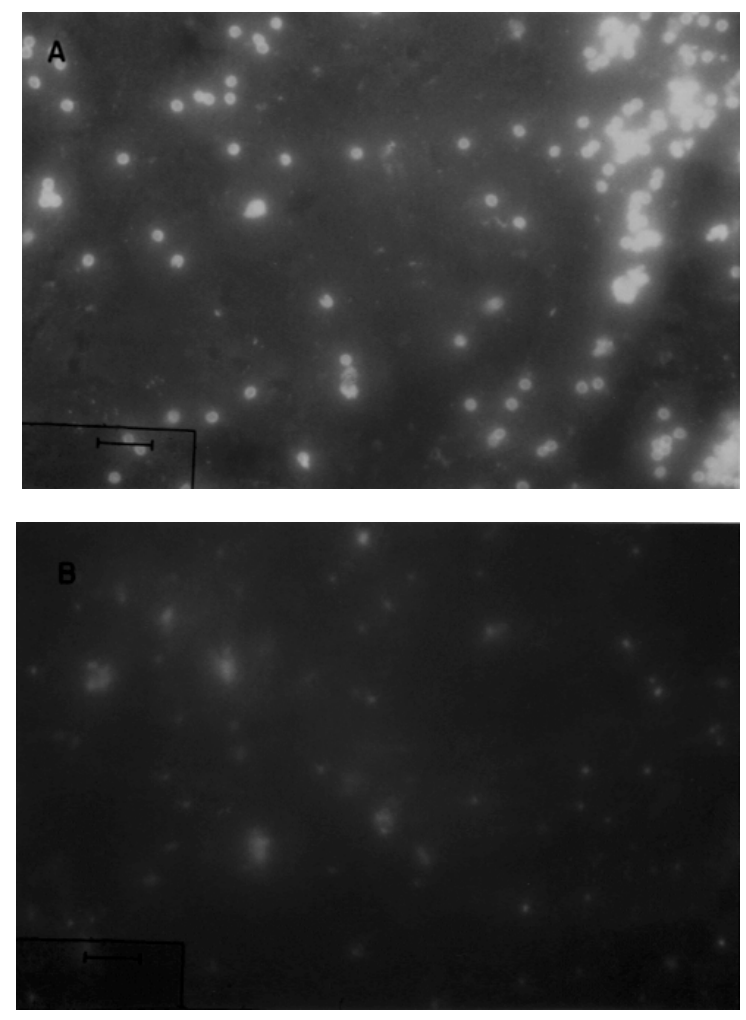

Figure 1 - Pattern of IgG immunofluorescence, of positive $(1: 40)(A)$ or negative $(1: 10)$ (B) sera (400X).

Tabela 1 - Distribution of IgG and IgM isotype reactivity by IIF among immunocompetent or immunodeficient child and adult patients, according to the excretion of oocysts in stools.

\begin{tabular}{|c|c|c|c|c|c|}
\hline \multirow[b]{3}{*}{ Isotypes/Patients status } & & \multicolumn{2}{|c|}{ Immunocompetent } & \multicolumn{2}{|c|}{ Immunodeficient } \\
\hline & & \multicolumn{4}{|c|}{ Oocysts in the stool } \\
\hline & & Yes & $\mathrm{No} / \mathrm{Nd}$ & Yes & $\mathrm{No} / \mathrm{Nd}$ \\
\hline \multirow[t]{4}{*}{$\lg G$} & & Positive $\%$ & Positive\% & Positive\% & Positive \% \\
\hline & Child & $8 / 13(62)$ & $1 / 5(20)$ & $1 / 7(14)$ & nd \\
\hline & Adult & $1 / 1(100)$ & $3 / 74(4)$ & $29 / 51(57)$ & $5 / 22(23)$ \\
\hline & Total & $9 / 14(64)$ & $4 / 79(5)$ & $30 / 58(52)$ & $5 / 22(23)$ \\
\hline \multicolumn{6}{|l|}{$\lg M$} \\
\hline & Child & $8 / 13(62)$ & $2 / 5(40)$ & $0 / 7(0)$ & nd \\
\hline & Adult & $1 / 1(100)$ & $9 / 74(12)$ & $1 / 51(2)$ & $0 / 22(0)$ \\
\hline & Total & $9 / 14(64)$ & $11 / 79(14)$ & $1 / 58(2)$ & $0 / 22(0)$ \\
\hline
\end{tabular}

No - negative

Nd - Not determined 
Sera were considered positive when this characteristic pattern was observed with a $1: 10$ or greater dilution of the sera for $\operatorname{IgG}^{10,24,25}$ and with 1:20 or greater dilution for IgM.

In order to detect eventual cross-reacting antibodies, sera reacting with both T.gondii and Cryptosporidium antigens were absorbed with $T$. gondii tachizoites. The titers of Cryptosporidium antibodies remained the same after clearing of $T$. gondii antibodies. Thus, cross-reacting antibodies were absent. Sera from patients with schistosomiasis, malaria, american trypanosomiasis, visceral leishmaniasis and giardiasis were negative in this test. Low or borderline positive titers were observed in few samples of sera from patients infected with Isospora belli and Toxoplasma gondii, which are closely related protozoa.

Of 72 sera samples from patients who excreted oocysts in their faeces, 39 had positive IgG titers (54\%), a higher frequency than in to groups $\mathrm{B}, \mathrm{E}$ and $\mathrm{H}$, patients which were negative (No) or with excretion of Cryptosporidium not determined (ND). In this group, only $9 / 101(9 \%)$ samples were positive $(\mathrm{p}<0.05)$.

When the different groups were analysed as one (Table 1), the immune status was unimportant, with IgG being detected in 9 of $14(64 \%)$ samples from immunocompetent patients, as compared to 30 of $58(52 \%)$ samples from immunocompromised patients. Detection of serum IgG was higher $(\mathrm{p}<0.05)$ in immunocompetent children, with 8 of 13 samples positive (62\%) in this group, as compared to 1 of 7 positive samples from immunocompromised children (14\%).

Serum samples from immunocompromised children also presented a lower frequency of detectable antibodies ( $1 / 7$ or $14 \%)$, as compared with immunocompromised adults, where 29 of 51 (57\%) samples were positive $(\mathrm{p}<0.05)$.

In the groups with negative (No) or excretion of oocysts not determined (Nd), the prevalence of specific IgG was higher in children $(20 \%)$, and immunocompromised adults $(23 \%)$ than in immunocompetent adults $(4 \%),(\mathrm{p}<0.05)$.

Those adult immunocompromised patients with Cryptosporidium in faeces had a frequency of positive $\operatorname{IgG}(57 \%)$ somewhat higher than patients from the same immune background (group G), who had specific IgG in 5 of $22(23 \%)$ serum samples $(\mathrm{p}<0.10)$.

As a whole, the numbers of IgM positive samples was similar in the oocyst excreting group (10/72 or $14 \%$ ) and the negative (No) or not determined for excretion of oocysts groups (ND) (11/101 or 11\%).
When sorted by immune status (Table 1), the oocyst excreting groups (A and D), had a larger number of samples with specific IgM ( 9 of 14 samples or $64 \%$ ), as compared to groups $\mathrm{C}$ and $\mathrm{F}$, of which 1 in 58 serum samples $(2 \%)$ were $\operatorname{IgM}$ positive $(\mathrm{p}<0.05)$. This pattern is also seen when 11 of 79 positive samples from immunocompetent negative/ not determined were compared with 22 samples from immunocompromised not determined group, which were IgM negative $(\mathrm{p}<0.05 \%)$. The same IgM pattern was seen in immunocompromised oocyst excreting children (group C).
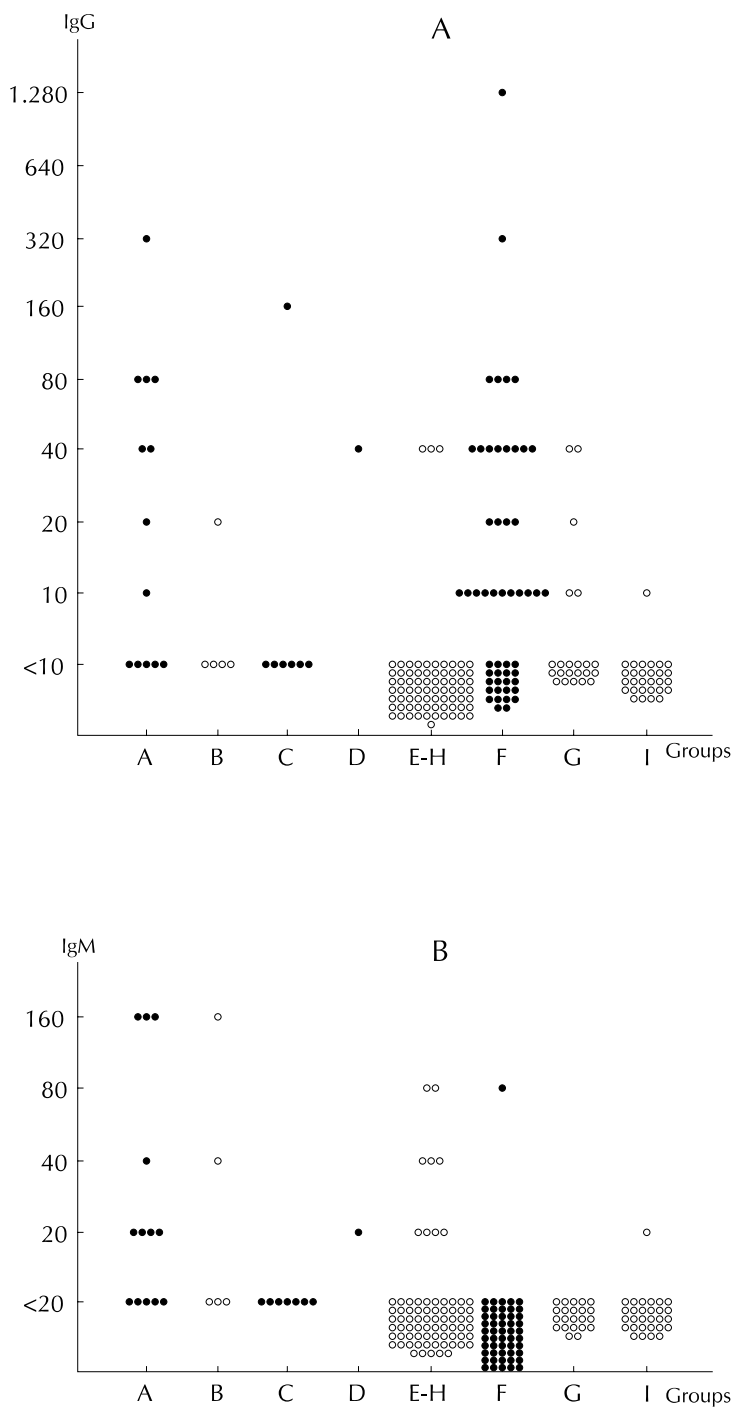

Figure 2 - Distribution of specific $\lg G$ titers (A) and IgM titers (B), by IIF, against oocysts of Crystosporidium in the Groups A, C, D, F (with excretion of oocysts) - and, B, E, G and I (with negative and not evaluated excretion of oocysts) $\mathrm{o}$. 
Simultaneous detection of specific $\operatorname{IgG}$ and $\operatorname{IgM}$ was found in $20 \%$ of sera from immunocompetent children (group B).

The titers of specific IgG and IgM for all groups of patients are shown in Figures 2-A (IgG) and 2-B (IgM). When positive, the observed titers were similar in all the groups studied. No unexpected by low values of $\mathrm{IgG}$ and $\mathrm{IgM}$ were observed in positive sera from immunocompromised patients. Eight serum samples from 5 patients, from which exact time intervals between collection of sera and the positive finding of oocyst excretion in faeces were defined, were analysed (Table 2). As expected, no IgM response could be detected in sera from immunocompromised patients, whereas the majority of serum samples from immunocompetent patients were IgM positive. The IgG titers increased with time and one patient from group A had eight-fold increment in titer.

The sensitivity of our IIF test was 59\% (calculated as defined by Galen and Gambino ${ }^{5}$ for groups A, D and F).

Tabela 2 - Correlation of IgM and IgG titers, in the sera of 3 immunocompetent infected children, from Group $\mathrm{A}$, and 2 immunodeficient infected adults, from Group $F$, with detection of oocysts in their faeces.

\begin{tabular}{lccc}
\hline Patients & $\begin{array}{c}\text { Time after detection of } \\
\text { oocysts in faeces }\end{array}$ & $\operatorname{lgM}$ & $\operatorname{lgG}$ \\
\hline Group A & 6 days & 160 & 80 \\
1-GAC & 3 days & - & 80 \\
2-WAG & 8 days & 20 & 40 \\
3- TBS & 31 days & 20 & 320 \\
& & & \\
Group F & 3 months & - & 40 \\
4-FMRA & 8 days & - & 10 \\
5-PRC & 4 months & - & 20 \\
& 6 months & - & 40 \\
\hline
\end{tabular}

\section{DISCUSSION}

As proposed, an IIF test for detection of serum antibodies against Cryptosporidium from infected patients and controls was developed and tested. Finding an adequate oocyst source was the initial problem. Stools from infected patients usually had low numbers of oocysts; the danger of HIV transmission existed ${ }^{18}$; nor could the interference of host antibodies in the test be reled out ${ }^{13,19}$. Experimental models in mice have shown a low yield of parasites ${ }^{4}$ and cellular culture is also limited by the lack of autoinfective forms ${ }^{17}$.

The elected source of antigen, infected calf stools $^{1}$, had a higher oocyst yield and few conta- minants. The purification process, though time consuming, provides adequate number of oocysts for IIF tests. This amount is insufficient for use in other tests such as ELISA or Western blot which require large quantities of purified antigens and in which it has been reported that $23 \mathrm{kDa}$ proteins reacted with the sera of $93 \%$ of persons with cryptosporidiosis ${ }^{27}$.

The IIF test described above, using purified oocysts from calf stools, provided clear and definite patterns of positive and negative sera, both for IgM and $\mathrm{IgG}$, without contaminants. Other sources of oocysts, like ileum from suckling mice infected with Cryptosporidium were also used elsewhere, but visualization of oocysts in this material requires highly trained observers ${ }^{2}$. The ELISA test for both immunoglobulin classes has been described but false positives occurred due to cross-reaction with antibodies from other infections ${ }^{24}$. In the above test, specific absorption studies were used to prove the specificity of the reaction, showing that the approach used provided specific antibody detection.

As in all other reported studies, the non-oocyst excreting group described in this report could not be clearly defined as never having had contact with Cryptosporidium. On the other hand, the low prevalence of antibodies in the group of oocyst excreting patients could be explained by the existence of immunological gaps in the antibody production, as described in other diseases of the Phylum Apicomplexa such as malaria and toxoplasmosis ${ }^{21}$. The present data were analysed in the light of these concerns.

The present data show a similar frequency of detection for both immunoglobulin classes in immunocompetent patients with known fecal excretion of Cryptosporidium oocysts. When specific serum IgG and IgM were measured in patients that had oocyst excretion not determined (groups $\mathrm{E}$ and $\mathrm{H}$ ), the prevalence was $4 \%$ and $12 \%$, respectively. This finding was quite similar to those of other reports, one employing IIF test ${ }^{3}$ and another ELISA ${ }^{24}$, both demonstrating a somewhat higher rate of detection of IgM and IgG in serum samples of patients from a general population with oocyst excretion not determined. The relatively higher than expected IgM frequency could be attributed to a constant antigenic challenge by frequent oocyst ingestion or to a persistent IgM immune response, specific to this parasite.

The percentage of serum samples with antiCryptosporidium $\mathrm{IgG}$ (4\%) in groups with oocyst excretion not determined ( $\mathrm{E}$ and $\mathrm{H}$ ) was similar to what has been reported in a study involving an Italian population $(5.3 \%)^{7}$. Higher prevalence of specific IgG 
(32\%), has been reported in the North American population, but this could represent higher environmental exposure or lower specificity of the test ${ }^{26}$.

The finding of specific IgG in the sera of oocyst excreting patients was expected, though the number of negative samples was quite high. We attributed this fact to the time of sample collection, probably early in the infection, when specific antibodies might not be detected ${ }^{27}$. In a small number of serially collected samples, a clear rise in antibody ttiter was seen, supporting this concept.

In immunocompromised patients who excreted oocysts, the immune status affected mainly the IgM response, with very few if any positive sera in this group, regardless of age. Similar findings were reported elsewhere, when only 4 of 26 patients had a positive IgM test by ELISA ${ }^{24}$. This fact could be explained by the low specific IgM response reported in patients with other acute protozoan diseases ${ }^{24}$. Another explanation was that low IgM was in fact an index of immunodeficiency, as observed in patients with hypogamaglobulinemia, were cryptosporidiosis develops as a chronic disease ${ }^{12,22}$, supporting the fact that a humoral response could be important in the control of disease. Laxer et al. ${ }^{13}$, examining immune response to cryptosporidiosis in immunocompetent Philippine children, demonstrated that $\operatorname{IgM}$ serum had the strongest binding response to surface structures on both oocysts and sporozoites, as determined by immunoelectron microscopy.

In immunocompetent children who were negative for excretion of oocysts in their faces, IgG and $\operatorname{IgM}$ were demonstrated in $20 \%$ of the samples. This finding can be explained by recent infection and by common exposure of children to this parasite. Studies of seroprevalence in Peru and Venezuela showed the simultaneous presence of specific $\operatorname{IgG}$ and $\operatorname{IgM}$ in $19.8 \%$ and $15.5 \%$, respectively, of the children examined ${ }^{25}$. The low percentage of serum samples with $\operatorname{IgG}(14 \%)$ and $\operatorname{IgM}(0 \%)$ in children with HIV (group $\mathrm{C}$ ) could be attributed to the immunodeficiency caused by HIV in this age group. We could not find reports of humoral response to Cryptosporidium in HIV infected children.

A higher frequency of IgG in the groups of immunocompetent children (group B) and immunocompromised adults (group $\mathrm{G}$ ), who were negative or with oocyst excretion not determined as compared to immunocompetent adults (groups $\mathrm{E}$ and $\mathrm{H}$ ), was also found. This finding could reflect a higher predisposition of those groups to infection with Cryptosporidium $^{8,11}$.

In conclusion, the present IIF test, despite its low sensitivity was able to differentiate between specific $\mathrm{IgG}$ and $\mathrm{IgM}$ serum in immunocompetent and immunocompromised (HIV) children and adults. This test has good specificity and could also be useful for epidemiological studies in immunocompet patients (adults and children) and immunocompromised adults. The low prevalence of anti-Cryptosporidium $\mathrm{IgG}$ and the lack of anti-Cryptosporidium IgM in immunocompromised children and the small number of samples with detectable IgM in immunocompromised adults needs further investigation.

\section{ACKNOWLEDGEMENT}

To Almir Robson Ferreira for graph and picture composition and to Eufrosina S. Umezawa, $\mathrm{PhD}$ and Jacyr Pasternak, MD, for helpful comments.

\section{REFERENCES}

1. ARROWOOD, M.J. \& STERLING, C.R. Isolation of Cryptosporidium oocysts and sporozoites using discontinuous sucrose and isopycnic Percoll gradients. $J$. Parasitol., 73: 314-9, 1987.

2. CAMPBELL, P.N. \& CURRENT, W.L. Demonstration of serum antibodies to Cryptosporidium sp. in normal and immunodeficient humans with confirmed infections. J. Clin. Microbiol., 18: 165-9, 1983.

3. CASEMORE, D.P. The antibody response to Cryptosporidium: development of a serological test and its use in a study of immunologically normal persons. J. Infect., 14: 125-34, 1987.
4. CURRENT, W.L. Techniques and laboratory maintenance of Cryptosporidium. In: Dubey, J.P.; Speer, C.A.; Fayer, R. Cryptosporidiosis of man and animals. Boca Raton, CRC Press, 1990. p.31-49.

5. GALEN, R.S. \& GAMBINO, S.R. Beyond normality: the predictive value and efficiency of medical diagnosis. New York, John Wiley \& Sons, 1975.

6. GARCIA, L.S.; BREWER, T.C.; BRUCKNER, D.A. Fuorescence detection of Cryptosporidium oocysts in human fecal specimens by using monoclonal antibodies. J. Clin. Microbiol., 25: 119-21, 1987. 
7. GOMEZ MORALES, M.A.; POZIO, E.; CROPPO, G.P. Serodiagnosis of cryptosporidiosis in Italian HIV-positive patients by means of an oocyst soluble antigen in an ELISA. J. Infect., 25: 229-36, 1992.

8. GUIZELINI, E. Pesquisa de oocistos de Cryptosporidium sp. nas fezes de pacientes com diarréia, mediante emprego de três técnicas de coloração. São Paulo, 1991. [Dissertação Mestrado - Instituto de Ciências Biomédicas da USP].

9. HEYMAN, M.B.; SHIGEKUNI, L.K.; AMMANN, A.J. Separation of Cryptosporidium oocysts from fecal debris by density gradient centrifugation and glass bead columns. $J$. Clin. Microbiol., 23: 789-91, 1986.

10. KOCH, K.L.; PHILLIPS, D.J.; ABER, R.C.; CURRENT, W.L. Cryptosporidiosis in hospital personnel. Evidence for person-to-person transmission. Ann. Intern. Med., 102: 593-6, 1985.

11. KUHLS, T.L.; MOSIER, D.A.; CRAWFORD, D.L.; GRIFFIS, J. Seroprevalence of cryptosporidial antibodies during infancy, childhood and adolescence. Clin. Infect Dis., 18: $731-5,1994$.

12. LASSER, K.H.; LEWIN, K.J.; RYNING, F.W. Cryptosporidial enteritis in a patient with congenital hypogammaglobulinemia. Hum. Pathol., 10: 234-40, 1979.

13. LAXER, M.A.; ALCANTARA, A.K.; JAVATO-LAXER, M.; MENORCA, D.M.; FERNANDO, M.T.; RANOA, C.P. Immune response to cryptosporidiosis in Philippine children. Am. J. Trop. Med. Hyg., 42: 131-9, 1990.

14. MA, P. \& SOAVE, R. Three-step stool examination for cryptosporidiosis in 10 homosexual men with protracted watery diarrhea. J. Infect. Dis., 147: 824-8, 1983.

15. MACFARLANE, D.E. \& HORNER-BRYCE, J. Cryptosporidiosis in wellnourished and malnourished children. Acta Pediatr. Scand., 76: 474-7, 1987.

16. MANN, E.D.; SEKLA, L.H.; EIBISCH, G. Cryptosporidium antibodies in Manitoba cattle: a pilot study using an indirect fluorescent antibody procedure. Can. Vet. J., 28: 126-8, 1987.

17. MULLER, H.M.; RANUCCI, L.; POZIO, E.; CRISANTI, A. A method for collecting large quantities of Cryptosporidium parasites. Parasitol. Today, 9: 261-6, 1993.
18. NELSON, J.A.; REYNOLDS-KOHLER, C.; MARGARETTEN, W.; WILEY, C.A.; REESE, C.E.; LEVY, J.A. Human immunodeficiency virus detected in bowel epithelium from patients with gastrointestinal symptoms. Lancet, 1(8580): 259-62, 1988.

19. O'DONOGHUE, P.J. Cryptosporidium and cryptosporidiosis in man and animals. Int. J. Parasitol., 25: 139-95, 1995.

20. PETERSEN, C. Cellular biology of Cryptosporidium parvum. Parasitol. Today, 9: 87-91, 1993.

21. REMINGTON, J. S. \& DESCARTES, G. Toxoplasmosis. In.: Remington, J.S. \& Klein, J.O. Infectious diseases of the fetus and new born infant. 3rd ed. Philadelphia, Saunders Comp., 1990. p. 148-69.

22. SLOPER, K.S.; DOURMASHKIN, R.R.; BIRD, R.B.; SLAVIN, G.; WEBSTER, A.D.B. Chronic malabsorption due to cryptosporidiosis in a child with immunoglobulin deficiency. Gut, 23: 80-2, 1982.

23. TZIPORI, S. Cryptosporidiosis in perspective. $A d v$. Parasitol., 27: 63-129, 1988.

24. UNGAR, B.L.P.; SOAVE, R.; FAYER, R.; NASH, T.E. Enzyme immunoassay detection of immunoglobulin $\mathrm{M}$ and $\mathrm{G}$ antibodies to Cryptosporidium in immunocompetent and immunocompromised persons. J. Infect. Dis., 153: 570-8, 1986.

25. UNGAR, B.L.P.; GILMAN, R.H.; LANATA, C.F.; PEREZSCHAEL, I. Seroepidemiology of Cryptosporidium infection in two Latin American populations. J. Infect. Dis., 157: 551-6, 1988.

26. UNGAR, B.L.P.; ,MULLIGAN, M.; NUTMAN, T.B. Serologic evidence of Cryptosporidium infection in US volunteers before and during Peace Corps Service in Africa. Arch. Intern. Med., 149: 894-7, 1989.

27. UNGAR, B.L.P. Cryptosporidiosis in humans (Homo sapiens). In: Dubey, J.P.; Speer, C.A.; Fayer, R. Cryptosporidiosis of man and animals. Boca Raton, CRC Press, 1990. p. 59-82.

28. WOOLSON, R.F. Statistical methods for the analysis of biomedical data. New York, John Wiley \& Sons, 1987.

29. ZU, S-X.; FANG, G-D.; FAYER, R.; GUERRANT, R.L. Cryptosporidiosis: Pathogenesis and immunology. Parasitol. Today, 8: 24-7, 1992. 